\title{
Quality Evaluation of Surface Layer in Highly Accurate Manufacturing
}

\author{
Stanislaw Legutko ${ }^{1}$, Grzegorz Krolczyk ${ }^{2}$, Jolanta Krolczyk ${ }^{3}$ \\ ${ }^{1}$ Faculty of Mechanical Engineering and Management, Poznan University of Technology, 3 Piotrowo Street, 60-965 Poz- \\ nan, Poland. stanislaw.legutko@put.poznan.pl
} ${ }^{2}$ Faculty of Production Engineering and Logistics, Opole University of Technology, 76 Prószkowska Street, 45-758
Opole, Poland. g.krolczyk@ po.opole.pl
${ }^{3}$ Department of Biosystems Engineering, Opole University of Technology, 76 Prószkowska Street, 45-758 Opole, Poland.
j.krolczyk@ po.opole.pl

Precise characterization of surface topography is very important in many engineering industries. This paper describes potential possibilities of using optical 3D (three dimensional) measurement methods in surface metrology. Surface integrity describes the status and attributes of the machined surface. This paper presents possibilities of using and measurements of surface integrity, namely the surface topography and the physical parameters of which are analysis of microstructure and microhardness of the surface layer.

Keywords: machining, optical microscopy, surface morphology, topography

\section{References}

[1] BANA, I. V. (2006). Manufacturing of High Precision Bores. Netherlands.

[2] SMITH, G. T. (2008). Cutting Tool Technology. Industrial Handbook. London, Springer -Verlag.

[3] MAHOVIC POLJACEK, S.; RISOVIC, D.; FURIC, K.; GOJO, M. (2008). Comparison of fractal and profilometric methods for surface topography characterization, Applied Surface Science, 254, 3449-3458.

[4] KLOCKE, F.; SETTINERI, L.; LUNG, D.; CLAUDIO PRIARONE, P.; ARFT, M. (2013). High performance cutting of gamma titanium aluminides: Influence of lubricoolant strategy on tool wear and surface integrity, Wear, 302, 1-2, 1136-1144.

[5] KROLCZYK, G.; LEGUTKO, S.; STOIĆ A. (2013). Influence of cutting parameters and conditions onto surface hardness of duplex stainless steel after turning process, Tehnički Vjesnik - Technical Gazette, 20, 6, 1077-1080.

[6] KROLCZYK, G.; LEGUTKO, S. (2013). The machinability of duplex stainless steel - solutions in practice, Manufacturing Technology, 13, 4, 473 - 478.

[7] KROLCZYK, G.; GAJEK, M.; LEGUTKO, S. (2013). Effect of the cutting parameters impact onto tool life in duplex stainless steel turning process, Tehnički Vjesnik - Technical Gazette, 20, 4, 587-592.

[8] KROLCZYK, G.; LEGUTKO, S.; RAOS, P. (2013). Cutting wedge wear examination during turning of duplex stainless steel, Tehnički Vjesnik - Technical Gazette, 20, 3, 413-418.

[9] MATHIA, T. G.; PAWLUS, P.; WIECZOROWSKI M. (2011). Recent trends in surface metrology, Wear, 271, 494-508.

[10] E. J. ABBOTT, F. A. FIRESTONE, (1933). Specifying surface quality, Mech. Eng., 55, 569-572.

[11] WIECZOROWSKI, M. (2001). Spiral sampling as a fast way of data acquisition in surface topography, Int. J. Mach. Tools Manuf., 41 2017-2022.

[12] BENNETT, J. M. (1991). Overview: sensitive techniques for surface measurement and characterization, Proc. SPIE, 1573 152-158.

[13] BENNETT, J.M. (1992). Recent developments in surface roughness characterization, Meas. Sci. Technol., 3 11191127.

[14] TIZIANI, H. J. (1989). Optical methods for precision measurements, Opt. Quant. Electron., $21256-282$.

[15] LEONHARDT, K. et al., (1988). Optical methods of measuring rough surfaces, Proc. SPIE, $100922-29$.

[16] RACHEL S. BOLTON-KING, J. PAUL O EVANS, CLIFTON L. SMITH, JONATHON D. PAINTER, DEREK F. Allsop and Wayne M. Cranton, (2010). What are the Prospects of 3D Profiling Systems Applied to Firearms and Toolmark Identification? AFTE Journal, 42, 1, 23-33. 
[17] WYANT, J. C. (2009). Optical Testing and Testing Instrumentation, College of Optical Sciences, University of Arizona.

[18] YOSHIZAWA, T., (2009). Handbook of optical metrology: Principles and applications, CRC Press, Boca Raton, Florida, USA.

[19] DOSBAEVA, G.K.; VELDHUIS, S.C.; ELFIZY, A.; FOX -RABINOVICH, G.; WAGG, T. (2010). Microscopic Observations on the Origin of Defects During Machining of Direct Aged (DA) Inconel 718 Superalloy, Journal of Materials Engineering and Performance, 19, 8, 1193-1198.

[20] Veldhuis, S.C.; Dosbaeva, G. K.; Elfizy, A.; Fox-Rabinovich, G. S.; WAGG, T. (2010). Investigations of White Layer Formation During Machining of Powder Metallurgical Ni-Based ME 16 Superalloy, Journal of Materials Engineering and Performance, 19, 7, 1031-1036.

[21] KROLCZYK, G.; NIESLONY, P.; LEGUTKO, S. (2013). Microhardness and Surface Integrity in turning process of duplex stainless steel (DSS) for different cutting conditions, Journal of Materials Engineering and Performance, DOI: 10.1007/s11665-013-0832-4.

[22] STĘPIEN, P. (2011). Deterministic and stochastic components of regular surface texture generated by a special grinding process, Wear, 271, 3-4, 3, 514-518.

[23] HLOCH, S.; VALÍČEK, J.; KOZAK, D. (2011). Preliminary results of experimental cutting of porcine bones by abrasive waterjet, Tehnicki Vjesnik - Technical Gazette, 18, 3, 467-470.

[24] BOUD, F.; CARPENTER, C.; FOLKES, J.; SHIPWAY, P.H. (2010). Abrasive waterjet cutting of a titanium alloy: The influence of abrasive morphology and mechanical properties on workpiece grit embedment and cut quality, Journal of Materials Processing Technology, 210, 15, 2197-2205.

[25] MAKEDONSKI, A. (2011). Unconventional machining method for enhancing the durability of tools and strength of the specimens bonded, Manufacturing Technology, 11, 49-55.

[26] CELIK, A.; YAMAN, H.; TURAN, S., KARA, A.; KARA, F. (2014). Effect of heat treatment on green machinability of SiAlON compacts, Journal of Materials Processing Technology, 214, 4, 767-774.

[27] KARANDIKAR, J. M.; ABBAS, A.E.; SCHMITZ, T.L. (2014). Tool life prediction using Bayesian updating. Part 1: Milling tool life model using a discrete grid method, Precision Engineering, 38, 1, 18-27.

[28] KROLCZYK, G.; LEGUTKO, S.; GAJEK M. (2013). Predicting the surface roughness in the dry machining of duplex stainless steel, Metalurgija, 52, 2, 259-262.

[29] NÁPRSTKOVÁ, N.; SVOBODOVÁ, J.; CAIS, J. (2013). Influence of strontium in AlSi7Mg0.3 alloy on the tool wear, Manufacturing Technology, 13, 3, 368-373. 